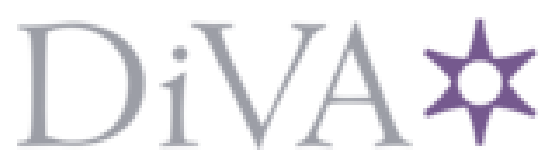

http://www.diva-portal.org

This is the published version of a paper published in Atmospheric Environment.

Citation for the original published paper (version of record):

Budhavant, K., Rao, P., Safai, P., Granat, L., Rodhe, H. (2014)

Chemical composition of the inorganic fraction of cloud-water at a high altitude site in West India.

Atmospheric Environment, 88: 59-65

http://dx.doi.org/10.1016/j.atmosenv.2014.01.039

Access to the published version may require subscription.

N.B. When citing this work, cite the original published paper.

Permanent link to this version:

http://urn.kb.se/resolve?urn=urn:nbn:se:su:diva-101085 


\title{
Chemical composition of the inorganic fraction of cloud-water at a high altitude station in West India
}

\author{
K.B. Budhavant ${ }^{\text {a,* }}$, P.S.P. Rao ${ }^{\text {b }}$, P.D. Safai ${ }^{\text {b }}$, L. Granat ${ }^{c}$, H. Rodhe ${ }^{c}$ \\ ${ }^{a}$ Maldives Climate Observatory-Hanimaadhoo, Hanimaadhoo, Maldives \\ ${ }^{\mathrm{b}}$ Indian Institute of Tropical Meteorology, Pune, Maharashtra, India \\ ' Department of Meteorology, Stockholm University, Stockholm, Sweden
}

\section{H I G H L I G H T S}

- Cloud water polluted but not acidic.

- High concentration of $\mathrm{Ca}^{2+}$.

- Some $\mathrm{SO}_{4}^{2-}$ may come from soil dust.

\section{A R T I C L E I N F O}

\section{Article history:}

Received 9 September 2013

Received in revised form

29 November 2013

Accepted 20 January 2014

\section{Keywords:}

Rainwater

Inorganic ions

Acidic deposition

$\mathrm{pH}$

\begin{abstract}
A B S T R A C T
Data from a ground-based cloud-water collection system intercepting water from clouds at a mountain field station, Sinhagad near Pune in India are presented. This study was part of an Indo-Swedish Collaboration Project on Atmospheric Brown Cloud-Asia (ABC-A). Cloud-water and rainwater (wetonly) samples were collected during June 2007-Dec. 2010. Concentrations of major anions and cations were determined. Ion concentrations were generally higher $\left(\mathrm{NO}_{3}^{-}\right.$, about 8 times; $\mathrm{SO}_{4}^{2-}$ and $\mathrm{K}^{+}, 5$ times; $\mathrm{NH}_{4}^{+}, 4$ times and $\mathrm{Cl}^{-}, \mathrm{Na}^{+}, \mathrm{Ca}^{2+}, \mathrm{Mg}^{2+} 3$ times) in cloud-water samples than in rainwater samples collected during the same days. The average $\mathrm{pH}$ of cloud-water samples was 6.0 with about $20 \%$ of the values below 5.6 and only $4 \%$ less than 5.0. Despite high concentrations of $\mathrm{SO}_{4}^{2-}$ and $\mathrm{NO}_{3}^{-}$the cloud water samples were on average not more acidic than rainwater samples. This is different from most of the other studies of cloud-water composition which have noted a substantially higher acidity (i.e. lower $\mathrm{pH}$ ) in cloud-water than in rainwater. The slightly alkaline $(\mathrm{pH}>5.6)$ nature of the cloud-water samples is mainly due to the presence of soil derived calcium carbonate in quantities more than enough to neutralize the acids or their precursors. A separation of the cloud-water data into trajectory groups showed that samples in air-masses having spent the last few days over the Indian sub-continent were in general more acidic (due to anthropogenic emissions) than those collected during days with air-masses of marine origin. A high correlation mutually between $\mathrm{Ca}^{2+}, \mathrm{Na}^{+}, \mathrm{NO}_{3}^{-}$and $\mathrm{SO}_{4}^{2-}$ makes it difficult to estimate the contribution to $\mathrm{SO}_{4}^{2-}$ from different sources. Anthropogenic $\mathrm{SO}_{2}$-emissions and soil dust may both give important contributions.
\end{abstract}

(c) 2014 Elsevier Ltd. All rights reserved.

\section{Introduction}

Chemical composition of rain and cloud-water is a particularly sensitive indicator of pollution emissions. Scavenging of aerosol particles and soluble trace gases by cloud droplets, followed by deposition through precipitation, removes large amounts of organic and inorganic pollutants from the atmosphere. Direct cloud-

\footnotetext{
* Corresponding author. +960 6520512, +960 7537185 (mobile).

E-mail addresses: kbbudhavant@gmail.com, kbbudhavant@yahoo.co.in (K. B. Budhavant).
}

deposition may also provide ecologically significant inputs (negative or positive) of nutrients and pollutants in certain mountain areas. A comparison between cloud-water and rainwater composition is of particular interest. It provides data that may be used to validate chemical transport and scavenging models.

Most of the cloud-water studies in Asia were conducted over China, Japan and Korea. However these studies have been concentrated on clouds in heavily polluted regions, with little information available on the chemical composition of cloud-water from remote locations and its relation to the chemical composition of precipitation. The lack of studies is especially true for south Asia. 
Recent studies in China (Wang et al., 2011) have reported cloud water $\mathrm{pH}$ as low as 2.56. Kim et al. (2006) observed a mean pH of cloud water of 4.7 at Daekwanreung in South Korea. In Japan, Igawa et al. (2002) measured cloud water at Mt. Oyama and investigated the factors influencing cloud water deposition.

Clouds can contribute well over 50\% to the deposition of sulfate and other pollutants at certain high elevations compared with rainfall and dry deposition (Marinoni et al., 2004). The concentrations of acids and other dissolved ions in cloud-water may vary greatly depending on different sources as seen from air-mass trajectory analyses (Ogren and Rodhe, 1986; Wang et al., 2011).

In the present study we present data on cloud-water ionic composition for a period of four years (2007-10) at Sinhagad, a mountain station in the Western Ghats near Pune in India. Our aim is to study the chemical composition of the inorganic fraction of chemical composition of the liquid phase of clouds and to identify possible sources for these species. Such detailed studies on the composition of cloud-water have not been reported before for this region and thus the data represent a new and unique data set.

\subsection{Methods}

Cloud-water and rainwater samples were collected at Sinhagad, a hill station about $40 \mathrm{~km}$ southwest of Pune $\left(18^{\circ} 21^{\prime} \mathrm{N}\right.$ and $73^{\circ} 45^{\prime} \mathrm{E}$, $1450 \mathrm{~m}$ amsl). It is a historical fort situated on a mountain top in the Western Ghat region. The top of the hill is almost flat with an area of about $0.5 \mathrm{~km}^{2}$. This part of the Western Ghat is mostly covered with vegetation (trees, grass) with some scattered hamlets. The only nearby source of pollution is wood burning for cooking. A few people live at the summit and some tourists visit this area (mainly by foot). The vehicles that enter the mountain stop at a distance of about $1 \mathrm{~km}$ away from the sampling site. In other directions the station is influenced by regional as well as long distance sources including those in west to central India with additional possible influence from the Indo-Gangetic Plains situated to the northeast (Momin et al., 2005; Gustafsson et al., 2009; Budhavant et al., 2009, 2012; Sheesley et al., 2012).

The cloud-water and rainwater (wet-only) collectors were originally designed at the Department of Meteorology, Stockholm University (MISU). Collectors were placed on a metal pole at a height of about $1.5 \mathrm{~m}$ and $2 \mathrm{~m}$, respectively from ground level. The cloud water collector consists of an exhaust fan placed on the back side of sampler. A plate having Teflon strings ( $0.5 \mathrm{~mm}$ diameter) is fixed on front side of sampler with $25^{\circ}$ slant angle, see Fig. 1. Whenever the ground cloud is present, the sampler was put on manually by an observer. The cloud then passes through the Teflon strings. Cloud-water droplets slide along the Teflon strings and are collected in a glass bottle attached just below the sampler as shown in Fig. 1. The samples were collected with a time resolution of 15-

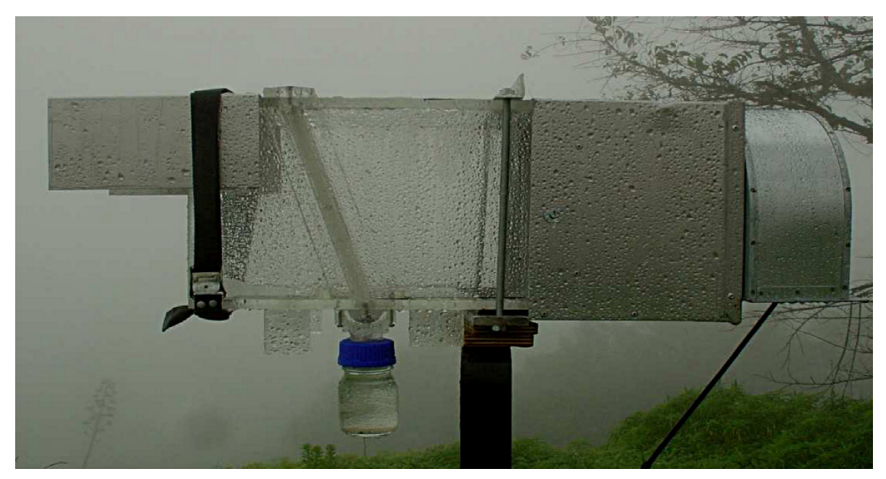

Fig. 1. Cloud-water collector.
120 min. "Wet-only" collector for rainwater collects only rain and not dry deposition as its lid remains open only during rain episodes. The collector has a funnel (diameter $\sim 20 \mathrm{~cm}$ ) and bottle $(2 \mathrm{~L})$ made of polyethylene. It consists of a cylindrical part with the funnel and bottle inside and a lid in polypropylene making a tight seal against the collector. The collection of rainwater samples were made at 10.00 am local time. Occasionally, samples were also collected at $17.00 \mathrm{pm}$ on the same day.

The samples were transferred to $100 \mathrm{ml}$ polyethylene bottles for shipping and analysis by ion chromatography (IC) using Analytical column AS4A-SC $4 \mathrm{~mm}, 1.8 \mathrm{mM} \mathrm{Na}_{2} \mathrm{CO}_{3} / 1.7 \mathrm{mM} \mathrm{NaHCO} 3$ as eluent and Anion Micro-Membrane Suppressor and Atomic Absorption Spectrophotometer, AAnalyst 400 (AAS) at IITM. Concentrations of major anions (chloride: $\mathrm{Cl}^{-}$, sulfate: $\mathrm{SO}_{4}^{2-}$ and nitrate: $\mathrm{NO}_{3}^{-}$) were measured using IC. AAS was used to analyze major cations i.e. sodium: $\mathrm{Na}^{+}$, Potassium: $\mathrm{K}^{+}$, Calcium: $\mathrm{Ca}^{2+}$ and Magnesium: $\mathrm{Mg}^{2+}$. The detection limit for ion chromatographic analysis was about $0.01 \mathrm{ppm}$ and that for the atomic absorption spectrophotometric analysis varied from 0.002 to $0.02 \mathrm{ppm}$. The $\mathrm{NH}_{4}^{+}$ion was measured by Indo-phenol Blue method (Weatherburn, 1967). $\mathrm{HCO}_{3}^{-}$was calculated from $\mathrm{pH}$ using the relation, $\mathrm{HCO}_{3}=10^{\mathrm{pH}-5.05}$ (Safai et al., 2004).

The quantity of each sample was determined by weighing on an electronic balance. To avoid biological degradation in the cloudwater and rainwater samples during storage and transport, a preservative (Thymol) was added in advance at MISU to the empty transport bottles (to give $400 \mathrm{mg}$ Thymol per $\mathrm{dm}^{3}$, Gillett and Ayers, 1991). By this procedure any spill of Thymol in the station environment was eliminated. All samples were stored in a refrigerator $\left(4^{\circ} \mathrm{C}\right)$ at the observatory and after arrival at IITM. $\mathrm{pH}$ was measured with Elico digital pH Meter (India) standardized at pH 4.0 and 9.2 with an accuracy of \pm 0.01 . Conductivity was measured with a digital conductivity meter calibrated against a reference $\mathrm{KCl}$ solution. Most of the time we measured $\mathrm{pH}$, conductivity and $\mathrm{NH}_{4}^{+}$ within 3-4 days after collection of samples and other analyses (at least for the cloud-water) within one month.

Field blank values were considered and the cloud and rainwater composition was corrected accordingly. Between two events, the cloud-water sampler was cleaned using large amounts of deionized (DI) water. Once the collector was cleaned, a blank was taken by spraying about $150 \mathrm{ml}$ of DI water onto the collection strands in the collector. Once a week the rainwater funnel was sprayed with de-ionized water (DI), and the runoff collected, weighed and treated in the same way as the rain samples. Sample from the DI in the spray bottle was also collected for later analysis. The brush used for cleaning was kept in a plastic bag between events. Plastic gloves were used during collection and analysis of cloud/rain samples. While analyzing the samples, several blanks were also analyzed that were kept under similar conditions as the cloud and rainwater samples.

All samples collected contained a certain amount of sea salt. This was calculated using the observed cloud and rain-water concentrations of $\mathrm{Na}^{+}$as the reference element and assuming that all $\mathrm{Na}^{+}$ is of marine origin (Keene et al., 1986). The non-sea salt concentration of any particular component " $X$ " is calculated based on the known sea water ratios with respect to $\mathrm{Na}^{+}$: [nss X] $=$ $\left[\mathrm{X}_{\text {rain }}\right]-\left[\mathrm{Na}_{\text {rain }}^{+}\right]\left\{\mathrm{X} / \mathrm{Na}^{+}\right\}_{\text {sea water }}$

\subsection{Data quality}

Quality control of the analyses was done based on laboratory produced test samples and certified reference samples. IITM has been participating in the international inter-comparison studies i.e., EANET's Inter-laboratory comparison projects and WMO's Laboratory Inter-comparison studies (LIS). The results from these 
Table 1

Statistical details of $\mathrm{pH}$ and various ionic concentrations [ $\mu$ eq $\mathrm{L}^{-1}$ ] in cloud-water at Sinhagad during 2007-10. 90\% confidence interval (assuming normal distributions).

\begin{tabular}{|c|c|c|c|c|c|c|c|c|c|c|c|c|c|}
\hline & $\mathrm{pH}$ & $\mathrm{NH}_{4}^{+}$ & $\mathrm{Cl}^{-}$ & $\mathrm{SO}_{4}^{2-}$ & $\mathrm{NO}_{3}^{-}$ & $\mathrm{Na}^{+}$ & $\mathrm{K}^{+}$ & $\mathrm{Ca}^{2+}$ & $\mathrm{Mg}^{2+}$ & $\mathrm{HCO}_{3}^{-}$ & Nss $\mathrm{SO}_{4}^{2-}$ & $\mathrm{Nss} \mathrm{Ca}^{2+}$ & Nss $\mathrm{Mg}^{2+}$ \\
\hline Average & 6.0 & 28 & 234 & 198 & 68 & 204 & 17 & 196 & 100 & 70 & 172 & 187 & 54 \\
\hline Maximum & 7.4 & 485 & 647 & 1007 & 403 & 690 & 91 & 1503 & 518 & 759 & 935 & 1483 & 460 \\
\hline Minimum & 4.7 & 0.1 & 10 & 16 & 0.1 & 8.9 & 0.7 & 13 & 5.4 & 0.4 & 10 & 12 & 2.9 \\
\hline Confidence interval & 0.1 & 6.4 & 16.0 & 16.1 & 7.5 & 13.3 & 1.4 & 21.6 & 8.7 & 9.7 & 15.0 & 21.7 & 7.1 \\
\hline
\end{tabular}

comparison studies showed good agreement i.e., the variation is within $\pm 20 \%$. The Ion balance and conductivity balance techniques were used to check the quality of the data. Under the ion balance check, ratio between the sum of cations and the sum of anions both in $\mu \mathrm{eq}^{-1}$ was estimated and samples outside $1.0 \pm 0.1$ were rejected. Similarly, samples were rejected if the ratio between the calculated and measured conductivity was outside $1.0 \pm 0.1 .19$ samples which failed this quality check were removed from the data set.

\section{Results and discussion}

\subsection{Overview of the data}

123 samples of cloud-water were analyzed and passed the quality check during the four years i.e. 2007-2010. A summary of the data is shown in Table 1 . The annual average $\mathrm{pH}$ of cloud-water was 6.0 indicating a persistent alkaline $(\mathrm{pH}>5.6)$ nature of cloudwater.

The high concentrations of $\mathrm{Na}^{+}$and $\mathrm{Cl}^{-}$are most likely due to influence from the up-stream marine source i.e. Arabian Sea. The average equivalent ratio of $\mathrm{Cl}^{-} / \mathrm{Na}^{+}$was 1.15 (Table 3 ) which is equal to that reported for sea water (Keene et al., 1986).

The inter-annual variations in annual mean concentrations are shown in Fig. 2. Most components vary in a similar manner; only $\mathrm{NH}_{4}^{+}$shows a distinctly different pattern. The low concentration in 2010 may at least partly be due to the relatively low number of samples from that year (16) compared to 36, 37 and 34 for the years 2007-2009 in combination with the fact that the samples this year were collected systematically towards the end of the monsoon season.

The correlations between component concentrations in individual samples are shown in Table $2 . \mathrm{Na}^{+}$and $\mathrm{Cl}^{-}$are very well correlated. High correlations also exist mutually between $\mathrm{Na}^{+}$, nss $\mathrm{SO}_{4}^{2-}, \mathrm{Ca}^{2+}, \mathrm{Mg}^{2+}$ and $\mathrm{NO}_{3}^{-}$.

\subsection{Air-mass back trajectories}

Seven days air-mass back trajectories ending at $1500 \mathrm{~m}$ above sea level for Sinhagad obtained from Hysplit, NOAA, USA were used to characterize the source regions for air masses impacting the study area (Fig. 3). It can be seen that on many occasions during the

Table 2

Correlation matrix for the concentration of ions in the cloud-water samples. Correlations higher than 0.8 are highlighted in bold.

\begin{tabular}{lcllllllll}
\hline & $\mathrm{Ca}^{2+}$ & $\mathrm{K}^{+}$ & $\mathrm{Mg}^{2+}$ & $\mathrm{Na}^{+}$ & $\mathrm{Cl}^{-}$ & $\mathrm{NO}_{3}^{-}$ & $\mathrm{SO}_{4}^{2-}$ & $\mathrm{Nss} \mathrm{SO}_{4}^{2-}$ & $\mathrm{NH}_{4}^{+}$ \\
\hline $\mathrm{Ca}^{2+}$ & 1 & & & & & & & & \\
$\mathrm{~K}^{+}$ & 0.79 & 1 & & & & & & & \\
$\mathrm{Mg}^{2+}$ & $\mathbf{0 . 8 4}$ & $\mathbf{0 . 8 7}$ & 1 & & & & & & \\
$\mathrm{Na}^{+}$ & 0.76 & 0.64 & 0.69 & 1 & & & & & \\
$\mathrm{Cl}^{-}$ & 0.78 & 0.66 & 0.73 & $\mathbf{0 . 9 7}$ & 1 & & & & \\
$\mathrm{NO}_{3}^{-}$ & 0.76 & 0.65 & 0.68 & 0.44 & 0.45 & 1 & & & \\
$\mathrm{SO}_{4}^{2-}$ & $\mathbf{0 . 8 6}$ & $\mathbf{0 . 8 3}$ & $\mathbf{0 . 8 4}$ & 0.64 & 0.63 & $\mathbf{0 . 8 3}$ & 1 & & \\
$\mathrm{NsS} \mathrm{SO}_{4}^{2-}$ & $\mathbf{0 . 8 5}$ & $\mathbf{0 . 8 2}$ & $\mathbf{0 . 8 4}$ & 0.61 & 0.61 & $\mathbf{0 . 8 4}$ & 1 & 1 & \\
$\mathrm{NH}_{4}^{+}$ & -0.05 & 0.01 & -0.08 & -0.20 & -0.21 & 0.39 & 0.3 & 0.3 & 1 \\
\hline
\end{tabular}

summer monsoon season (June-September) winds coming from northern Indian Ocean were touching the east coast of the African continent before passing through Arabian Sea and reaching the sampling location. Hence, there is a possibility of long-range transport of polluted air-masses to the Sinhagad region from the East African/Gulf Coast. On some of the occasions, mainly during non-monsoon periods, winds were from either the north or northwest and traveled over land for several days, before reaching the sampling location, see Fig. 4.

\subsection{Variation of ionic composition by air mass}

Fig. 5 shows the volume weighted mean chemical composition of cloud water for the two different types of air-masses, i.e. airmasses originating from marine areas and a few (5) cases when air-masses originating from land areas. The concentrations of $\mathrm{Cl}^{-}$, $\mathrm{Na}^{+}$and $\mathrm{Mg}^{2+}$ were higher in air masses of marine origin. All other ions were more abundant in air-masses originating from land. During the summer monsoon period with trajectories entering the station from the west the patterns were surprisingly similar within the years and between years, as shown in Fig. 2

\section{4. $\mathrm{pH}$}

The $\mathrm{pH}$ is the result of the overall influence of acidic and alkaline components, originating from their respective sources, anthropogenic as well as natural. Acidic components like precursors of $\mathrm{NO}_{3}^{-}$ and $\mathrm{SO}_{4}^{2-}$ are generally emitted from industrial and vehicular sources, but soil dust is another possible source of $\mathrm{SO}_{4}^{2-}$. The most important source of $\mathrm{Ca}^{2+}$ is most likely soil dust. Also, certain sources such as construction activities give rise to emissions of components containing $\mathrm{Ca}^{2+}$. The use of fertilizers that activate soil microbial reactions, give rise to emissions of $\mathrm{NH}_{3}$ that can end up as $\mathrm{NH}_{4}^{+}$in cloud-water. The frequency distribution of $\mathrm{pH}$ (Fig. 6) shows a maximum in the range of 6.6-7.0. The average cloud-water $\mathrm{pH}$ was 6.0 . Almost $20 \%$ of cloud-water samples were found to be acidic ( $\mathrm{pH}<5.65$ ) but only $4 \%$ were below 5.0. The lowest value measured was 4.39 . The low $\mathrm{pH}$ values generally occurred during the nonmonsoon season when the air mass trajectories originated from land (Fig. 4). The high pH of cloud-water at Sinhagad compared to most other studies (e.g. Blas et al., 2008) is due to the high concentrations of neutralizing components especially associated with $\mathrm{Ca}^{2+}$ compared to the acidifying ones.

\subsection{Cloud-water versus wet-only rainwater chemistry}

All the ionic components were found to be more abundant in cloud-water than in rainwater, c.f. Fig. 7. The ratio between the total

Table 3

Comparison of sea water ratios with cloud water and rainwater (collected during the same day) ratios with respect to $\mathrm{Na}^{+}$.

\begin{tabular}{llllll}
\hline & $\mathrm{Cl}^{-} / \mathrm{Na}^{+}$ & $\mathrm{SO}_{4}^{2-} / \mathrm{Na}^{+}$ & $\mathrm{K}^{+} / \mathrm{Na}^{+}$ & $\mathrm{Mg}^{2+} / \mathrm{Na}^{+}$ & $\mathrm{Ca}^{2+} / \mathrm{Na}^{+}$ \\
\hline Cloud water & 1.15 & 0.97 & 0.08 & 0.49 & 0.96 \\
Rainwater & 1.12 & 0.59 & 0.06 & 0.41 & 0.92 \\
Sea water ratio & 1.17 & 0.13 & 0.02 & 0.23 & 0.04 \\
\hline
\end{tabular}




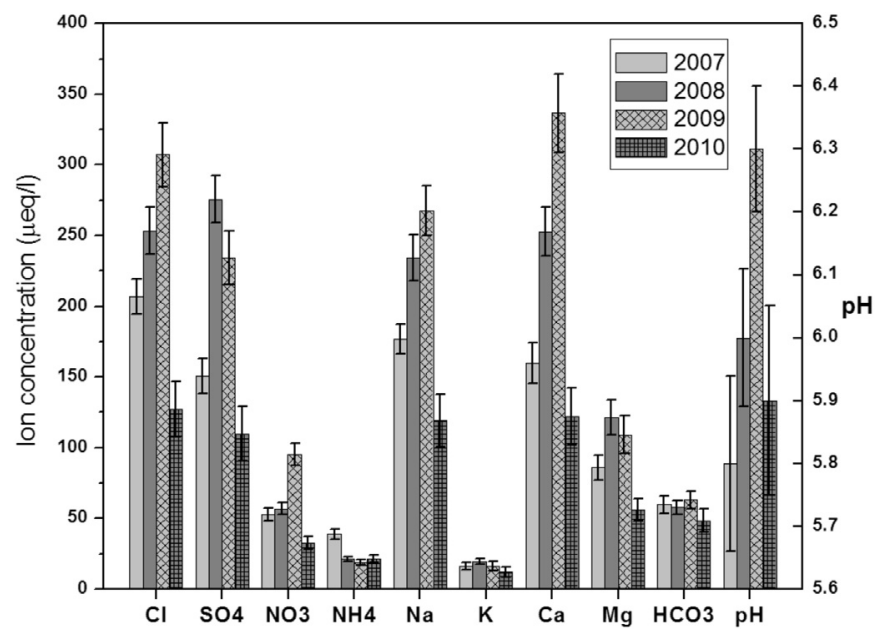

Fig. 2. Annual volume weighted average concentrations and average $\mathrm{pH}$ of cloudwater at Sinhagad, 2007-10. Vertical lines represent the confidence intervals (90\%).

ionic constituents (TIC) in cloud-water and in rainwater was about 3 while for the individual components the ratios were 8 for $\mathrm{NO}_{3}^{-} ; 5$ for $\mathrm{SO}_{4}^{2-}$ and $\mathrm{K}^{+} ; 4$ for $\mathrm{NH}_{4}^{+}$, and 3 for $\mathrm{Cl}^{-}, \mathrm{Na}^{+}, \mathrm{Ca}^{2+}$, and $\mathrm{Mg}^{2+}$. The high ratios for $\mathrm{NO}_{3}^{-}$and $\mathrm{SO}_{4}^{2-}$ might be interpreted as if these components had substantial contributions from gaseous precursors. Similar results were reported (Blas et al., 2008) for Western
Sudet Mountains, Poland where ionic concentrations in cloudwater were typically 3 to 5 times higher than those in rainwater. However, even though concentrations of both $\mathrm{SO}_{4}^{2-}$ and $\mathrm{NO}_{3}^{-}$in our study were much higher in cloud-water than in rainwater, this was not reflected in low $\mathrm{pH}$ values. Cloud-water $\mathrm{pH}$ was actually slightly higher than that of rainwater. This can be attributed to high concentrations of neutralizing components.

\subsection{Source categorization of ions in cloud-water}

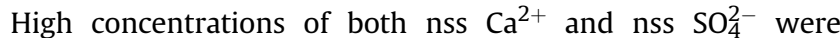
measured also during the summer monsoon season, possibly due to long-range transport from the easternmost part of the African continent or the southern part of the Arabian peninsula. However, possibility of incorporation of soil dust from coastal Indian region during the transport cannot be ruled out.

It is seen from Table 2 that all the components except $\mathrm{NH}_{4}^{+}$are well correlated with each other. Scatter-plots (not shown) clearly indicate that the high correlations are not artefacts produced from just a few samples with very high concentrations. $\mathrm{NH}_{4}^{+}$is only weakly correlated with $\mathrm{NO}_{3}^{-}$. The strong correlation and a ratio near that of sea salt between $\mathrm{Cl}^{-}$and $\mathrm{Na}^{+}$indicates that these components have a marine origin. Based on enrichment factors (see below) it is likely that part of the $\mathrm{Mg}^{2+}$ and a minor part of $\mathrm{Ca}^{2+}$ is also from sea salt. The relatively high correlation between $\mathrm{Ca}^{2+}$ and the sea salt components is surprising. It seems to indicate a substantial content of sea salt components in soil dust. Another
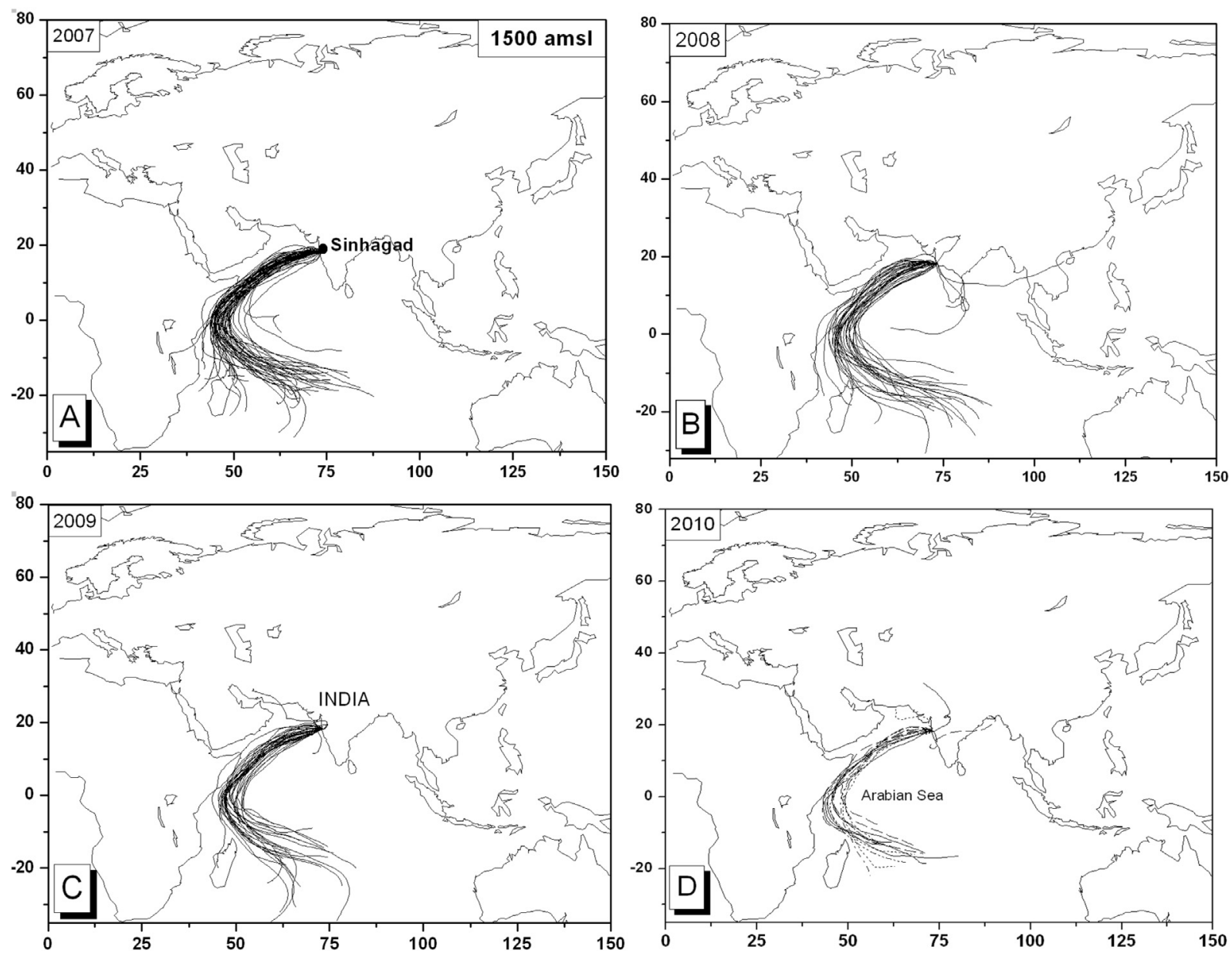

Fig. 3. Air mass trajectories for 7 days ending at Sinhagad at $1500 \mathrm{~m}$ above sea level during 2007-10. 


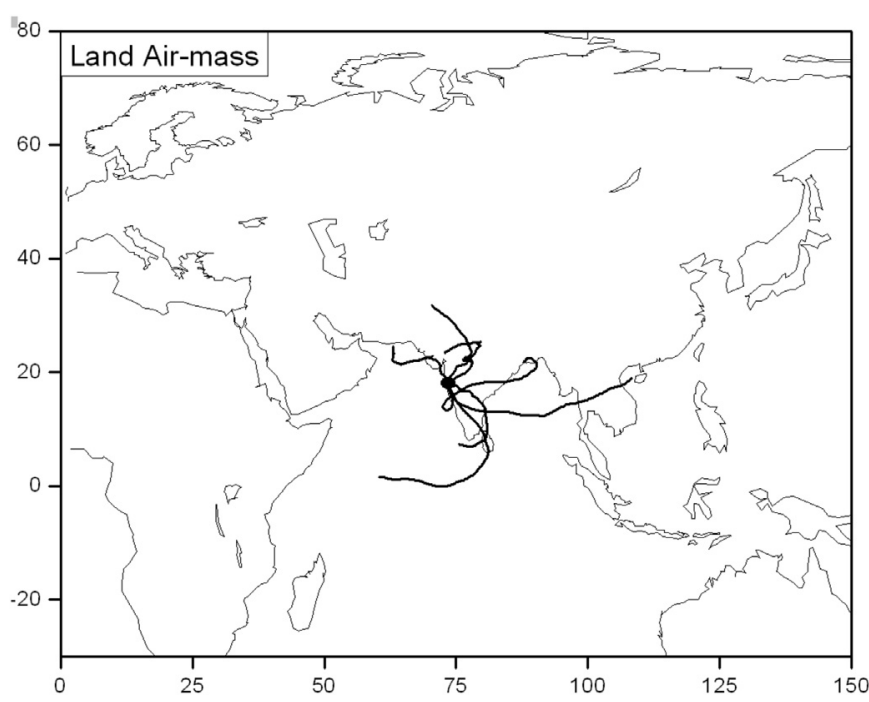

Fig. 4. Air-mass trajectories for 7 days ending at Sinhagad from land regions, 20072010.

hypothetical explanation may be emissions of $\mathrm{Ca}^{2+}$ from the ocean surface. As outlined by Das et al. (2011), it is possible that some of the $\mathrm{Ca}^{2+}$ originates from marine gels present in the ocean surface layer (uppermost $\mathrm{mm}$ ). Such gels have been shown to be an important component of the tropical marine aerosol (Bigg and Leck, 2008).

Nss $\mathrm{SO}_{4}^{2-}$ showed good correlation with nss $\mathrm{Ca}^{2+}, \mathrm{K}^{+}$and nss $\mathrm{Mg}^{2+}$ but not with $\mathrm{NH}_{4}^{+}$. This appears to indicate that a substantial fraction of the $\mathrm{SO}_{4}^{2-}$ was in the form of salts originating from soils but other sources can contribute as well. The high correlation between $\mathrm{Ca}^{2+}$ and $\mathrm{Na}^{+}$may however indicates a more complex process. Jain et al. (2000) have reported significant amounts of nss $\mathrm{SO}_{4}^{2-}$ in rainwater at Delhi, contributed by soil. $\mathrm{SO}_{4}^{2-}$ in rainwater has been reported as due to the re-suspension of gypsiferous soil dust in India (Jacks et al., 1994). Naik et al. (1988) have reported similar results for rainwater at Pune and surrounding rural areas. Khemani et al. (1982) have shown a bimodal size distribution for $\mathrm{SO}_{4}^{2-}$ aerosols at Pune during the monsoon season, with a major portion of mass in coarse fraction. It was suggested that atmospheric $\mathrm{SO}_{2}$ may be adsorbed on particulate matter and thereby react with either soil-derived components like $\mathrm{Ca}^{2+}, \mathrm{Mg}^{2+}$ and $\mathrm{K}^{+}$ or with marine component like $\mathrm{Na}^{+}$. Our earlier studies reported

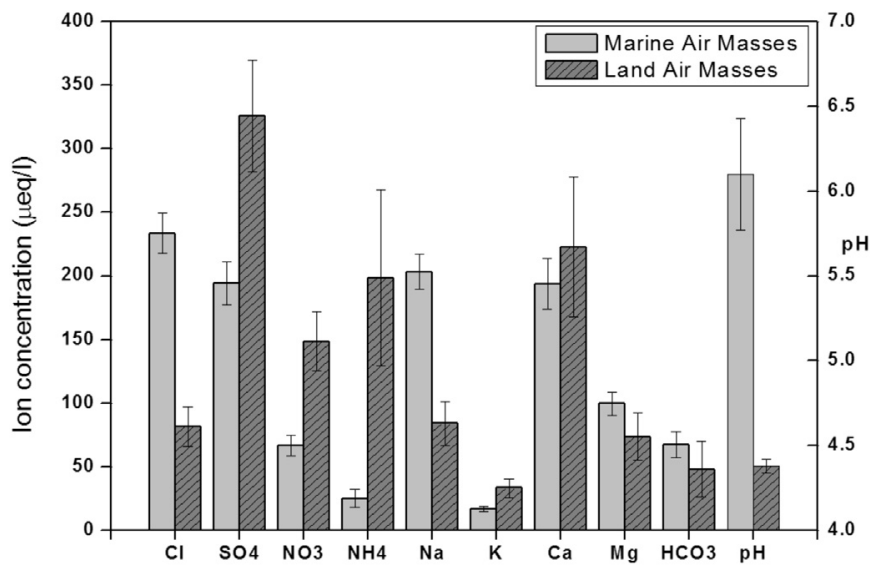

Fig. 5. Chemical composition of cloud-water from marine (light gray) and land (lines with dark gray) air masses Vertical lines represent the confidence intervals (90\%).

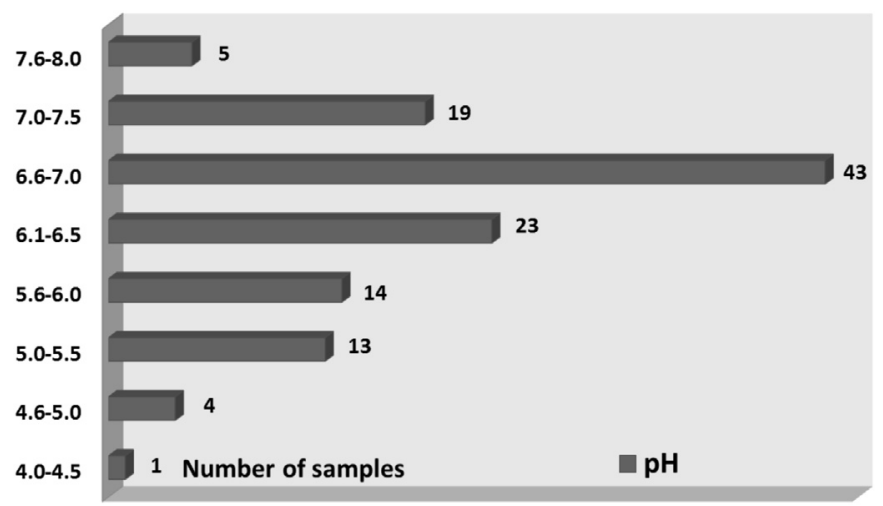

Fig. 6. Frequency distribution of $\mathrm{pH}$ in cloud water at Sinhagad during 2007-10, gray bars represent number of samples.

that $\mathrm{SO}_{4}^{2-}$ showed good correlation with $\mathrm{Ca}^{2+}$ in rain-water at Pune (Safai et al., 2004).

\subsection{Ionic ratios}

Ionic ratios for rainwater and cloud water were compared with that of Sea water in Table 3. Sea water ionic ratios were taken from the standard marine composition (Goldberg et al., 1971). It can be seen that except $\mathrm{Cl}^{-}$to $\mathrm{Na}^{+}$all other ratios like $\mathrm{SO}_{4}^{2-} / \mathrm{Na}^{+}, \mathrm{Ca}^{2+} / \mathrm{Na}^{+}$, $\mathrm{Mg}^{2+} / \mathrm{Na}^{+}$and $\mathrm{K}^{+} / \mathrm{Na}^{+}$were much higher compared to the standard marine values. These elevated values indicated the contribution from anthropogenic and crustal sources for both rain and cloud water composition at Sinhagad. In case of $\mathrm{Cl}^{-} / \mathrm{Na}^{+}$, their ratio values are very close to that of sea water indicating that both $\mathrm{Cl}^{-}$and $\mathrm{Na}^{+}$ are from marine origin.

\subsection{Neutralization factors}

The role of $\mathrm{Na}^{+}$and $\mathrm{Cl}^{-}$in either acid production or neutralization is negligible, since they mostly originate from sea in the form of sea salt. Neutralization Factors (NFs) is a measure of which cation has contributed most towards neutralization of acidity. NFs were computed for different alkaline constituents using the formulae

$$
\mathrm{NFX}=\frac{\mathrm{X}}{\left[\mathrm{NO}_{3}^{-}+\mathrm{nss} \mathrm{SO}_{4}^{2-}\right]}
$$

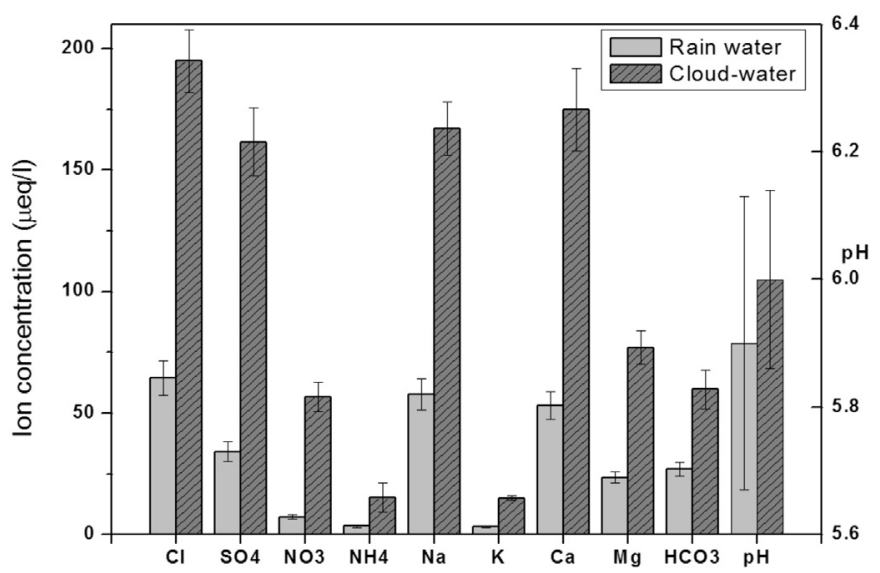

Fig. 7. Comparison of ionic concentrations in rain (light gray) and cloud-water (lines with dark gray) at Sinhagad. Vertical lines represent the confidence intervals (90\%). 
Table 4

Comparison of average ionic concentrations of cloud-water measured in the present study with those from other regions [ $\mu$ eq $\mathrm{L}^{-1}$ ].

\begin{tabular}{|c|c|c|c|c|c|c|c|c|c|c|c|c|}
\hline Sampling sites & Height & Period & $\mathrm{pH}$ & $\begin{array}{l}\text { Conductivity } \\
\left(\mu \mathrm{S} \mathrm{cm}^{-1}\right)\end{array}$ & $\mathrm{NH}_{4}^{+}$ & $\mathrm{SO}_{4}^{2-}$ & $\mathrm{NO}_{3}^{-}$ & $\mathrm{Ca}^{2+}$ & $\mathrm{Mg}^{2+}$ & $\mathrm{Na}^{+}$ & $\mathrm{K}^{+}$ & $\mathrm{Cl}^{-}$ \\
\hline Present study & $1450 \mathrm{~m}$ & $2007-10$ & 6.0 & 86 & 28 & 198 & 68 & 196 & 100 & 204 & 17 & 234 \\
\hline Clingmans dome $^{\mathrm{a}}$ (U.S) & $2014 \mathrm{~m}$ & 2010 & - & - & 170 & 225 & 110 & 65 & 21 & 38 & 5 & 23 \\
\hline Mt. Taishan ${ }^{\mathrm{b}}$ (China) & $1534 \mathrm{~m}$ & 2007 & 3.7 & 40 & 1376 & 1332 & 772 & 626 & 71 & 60 & 83 & 156 \\
\hline Szrenica $^{\mathrm{C}}$ (Poland) & $1330 \mathrm{~m}$ & $2005-06$ & 4.6 & 80 & 210 & 200 & 240 & 140 & 49 & 100 & 45 & 100 \\
\hline Stog Izerski ${ }^{\mathrm{d}}$ (Poland) & $1110 \mathrm{~m}$ & $2003-04$ & 4.4 & 69 & 190 & 68 & 177 & 32 & 14 & 101 & 21 & 97 \\
\hline
\end{tabular}

a U.S. EPA (2012).

b Wang et al. (2011).

c Blas et al. (2010).

d Blas et al. (2008).

Where $\mathrm{X}=$ the cation for which $\mathrm{NF}$ is calculated e.g. nss $\mathrm{Ca}^{2+}$, $\mathrm{nsSK}^{+}, \mathrm{NH}_{4}^{+}$or $\mathrm{nss} \mathrm{Mg}^{2+} . \mathrm{Ca}^{2+}$ ion served as the major neutralizing component for cloud-water acidity. The suspended particulate matter, rich in carbonates or bicarbonates of $\mathrm{Ca}^{2+}$ buffers the acidity of cloud-water, which is commonly observed in India (Safai et al., 2010; Shukla and Sharma, 2010; Budhavant et al., 2011). This is different from the situation in e.g. $\mathrm{NE}$ India where $\mathrm{NH}_{4}^{+}$is at least as important as $\mathrm{Ca}^{2+}$ (Norman et al., 2001). The order of neutralization (relative contribution in percentage) in the present study was $\mathrm{Ca}^{2+}(0.77)>\mathrm{Mg}^{2+}(0.23)>\mathrm{NH}_{4}^{+}(0.13)>\mathrm{K}^{+}(0.06)$.

There are certain distinct differences in ionic composition of cloud-water samples analyzed in the present study as compared to those reported for other regions, c.f. Table 4. The concentrations of $\mathrm{Na}^{+}, \mathrm{Cl}^{-}$and $\mathrm{Mg}^{2+}$ at Sinhagad are much higher compared to those reported for other sites. The concentration of $\mathrm{Ca}^{2+}$ is also high compared to all other sites except at Mt. Taishan, North China where $\mathrm{Ca}^{2+}$ is three times higher than at Sinhagad. This Chinese site is clearly strongly affected by pollution sources giving rise to very high concentrations of $\mathrm{NH}_{4}^{+}, \mathrm{SO}_{4}^{2-}$ and $\mathrm{NO}_{3}^{-}$. The low concentration of $\mathrm{NO}_{3}^{-}$compared to $\mathrm{SO}_{4}^{2-}$ at Sinhagad is might possibly be interpreted as if not all of the $\mathrm{SO}_{4}^{2-}$ is derived from combustion and other anthropogenic activities.

\section{Conclusions}

Unlike most previous studies of cloud-water composition our cloud-water samples were not more acidic than that of simultaneously collected rainwater samples despite the higher concentrations of $\mathrm{SO}_{4}^{2-}$ and $\mathrm{NO}_{3}^{-}$in cloud-water. This is mainly due to the presence of high concentration of soil derived calcium carbonate.

The average $\mathrm{pH}$ of cloud-water samples was 6.0 with about $20 \%$ of the values below 5.6 and only $4 \%$ less than 5.0. This indicates that cloud-water deposition is not an important pathway for deposition of acidity at this site. However, cloud water was quite acidic (average $\mathrm{pH}=4.5$ ) during a few cases in non-monsoon periods.

Air-mass back trajectory analysis, indicate that long range transport of pollutants and soil dust from East Africa and Southern part of the Arabic peninsula might contribute to the high concentrations of some of the ionic constituents at Sinhagad during the monsoon period. A high correlation between $\mathrm{Ca}^{2+}$ and sea salts indicates either a marine source, other than sea salt, for $\mathrm{Ca}^{2+}$ or a substantial input of soil dust containing sea salt.

Surprisingly high correlation was observed between $\mathrm{Ca}^{2+}$ and $\mathrm{SO}_{4}^{2-}$ indicating a common source (e.g. soil dust) of these components.

\section{Acknowledgment}

Authors are grateful to Director, IITM and Head, PM\&A Division, IITM, Pune for their encouragement. We thank Dr. Ali, Dr. Chate, Mr.
Momin, Mr. Gaikwad and Mr. Pader for their help in the field study. We also thank to Miss. Ranjeeta Gawhane and Mr. M. P. Raju for helping in the laboratory work. Also, authors are thankful to Department of Meteorology, Stockholm University MISU), Sweden for providing the cloud and rain collection gadgets and BSNL authorities for their cooperation and providing space at their microwave tower station at Sinhagad. Mr. Leif Bäcklin at MISU built the sampling equipment, including the cloud-water collector. We appreciate helpful comments on the manuscript by Prof. Caroline Leck. Financial support from Swedish International Development Cooperation Agency (Sida) through the ABC project is gratefully acknowledged.

\section{References}

Blas, M., Sobik, M., Twarowski, R., 2008. Changes of cloud water chemical composition in the Western Sudety Mountains, Poland. Atmos. Res. 87, 224231.

Blas, M., Polkowska, Z., Sobik, M., Klimaszewska, K., Nowinski, K., Namiesnik, J., 2010. Fog water chemical composition in different geographic regions of Poland. Atmos. Res. 95, 455-469.

Bigg, E.K., Leck, C., 2008. The composition of fragments of bubbles bursting at the ocean surface. J. Geophys. Res. 113, D11209. http://dx.doi.org/10.1029/ 2007JD009078.

Budhavant, K.B., Rao, P.S.P., Safai, P.D., Ali, K., 2009. Chemistry of monsoon and postmonsoon rains at a high altitude location, Sinhagad, India. Aerosol Air Qual. Res. 9, 65-79.

Budhavant, K.B., Rao, P.S.P., Safai, P.D., Ali, K., 2011. Influence of local sources on rainwater chemistry over Pune region, India. Atmos. Res. 100, 121-131.

Budhavant, K.B., Rao, P.S.P., Safai, P.D., Gawhane, R.D., Raju, M.P., Mahajan, C.M. Satsangi, P.G., 2012. Atmospheric wet and dry depositions of ions over an urban location in South-West India. Aerosol Air Qual. Res. 12, 561-570.

Das, R., Granat, L., Leck, C., Praveen, P.S., Rodhe, H., 2011. Chemical composition of rainwater at Maldives Climate Observatory at Hanimaadhoo (MCOH). Atmos. Chem. Phys. 11, 3743-3755.

Gillett, R.W., Ayers, G.P., 1991. The use of thymol as a biocide in rainwater samples. Atmos. Environ. 25 (12), 2677-2681.

Goldberg, E.D., Broecker, W.S., Gross, M.G., Turekian, K.K., 1971. Marine chemistry In: Radioactivity in the Marine Environment. National Academy of Sciences, Washington, DC, pp. 137-146.

Gustafsson, O., Krusa, M., Zencak, Z., Sheesley, R.J., Granat, L., Engstrom, E., Praveen, P.S., Rao, P.S.P., Leck, C., Rodhe, H., 2009. Brown clouds over South Asia: biomass or fossil fuel combustion? Science 323, 495-498.

Igawa, M., Matsumura, K., Okochi, H., 2002. High frequency and large deposition of acid fog on high elevation forest. Environ. Sci. Technol. 36, 1-6.

Jacks, G., Sharma, V.P., Torssander, P., Oberg, G., 1994. Origin of sulphur in soil and water in a precambrian terrain. Geochem. J. 28, 351-358.

Jain, M., Kulshrestha, U.C., Sarkar, A.K., Parashar, D.C., 2000. Influence of crusta aerosols on wet deposition at urban and rural sites in India. Atmos. Environ. 34 5129-5137.

Keene, W.C., Pszenny, A.P., Galloway, J.N., Hawley, M.E., 1986. Sea-sat corrections and interpretations of constituent ratios in marine precipitation. J. Geophys Res. 91, 6647-6658.

Khemani, L.T., Momin, G.A., Naik, M.S., Vijayakumar, R., Ramana Murty, Bh.V., 1982. Chemical composition of size distribution of atmospheric aerosols over the Deccan Plateau, India. Tellus 34, 151-158.

Kim, M.G., Lee, B.K., Kim, H.J., 2006. Cloud/fog water chemistry at a high elevation site in South Korea. J. Atmos. Chem. 55, 13-29.

Marinoni, A., Laj, P., Sellegri, K., Mailhot, G., 2004. Cloud chemistry at the Puy de Dome: variability and relationships with environmental factors. Atmos. Chem. Phys. 4, 715-728.

Momin, G.A., Ali, K., Rao, P.S.P., Safai, P.D., Chate, D.M., Praveen, P.S., Rodhe, H., Granat, L., 2005. Study of chemical composition of rainwater at an urban (Pune) 
and a rural (Sinhagad) location in India. J. Geophys. Res. 110, D08302. http:// dx.doi.org/10.1029/2004JD004789.

Naik, M.S., Khemani, L.T., Momin, G.A., Prakasa Rao, P.S., 1988. Measurement of pH and chemical analysis of rainwater in rural area of India. Acta Meteorol. Sin. 2, $91-100$.

Norman, M., Das, S.N., Pillai, A.G., Granat, L., Rodhe, H., 2001. Influence of air mass trajectories on the chemical composition of precipitation in India. Atmos. Environ. 35 (25), 4223-4235.

Ogren, J., Rodhe, H., 1986. Measurements of the chemical composition of cloudwater at a clean air site in central Scandinavia. Tellus 38B, 190-196.

Safai, P.D., Budhavant, K.B., Rao, P.S.P., Ali, K., Sinha, A., 2010. Source characterization for aerosol constituents and changing roles of calcium and ammonium aerosols in the neutralization of aerosol acidity at a semi-urban site in SW India. Atmos. Res. 98, 78-88.

Safai, P.D., Rao, P.S.P., Momin, G.A., Ali, K., Chate, D.M., Praveen, P.S., 2004. Chemical composition of precipitation during 1984-2002 at Pune, India. Atmos. Environ. $38,1705-1714$.
Sheesley, R.J., Kirillova, E.J., Andersson, A., Krusa, M., Praveen, P.S., Budhavant, K.B., Safai, P.D., Rao, P.S.P., Gustafsson, O., 2012. Year-round radiocarbon-based source apportionment of carbonaceous aerosols at two background sites in South Asia. J. Geophys. Res. 117, D10202. http://dx.doi.org/10.1029/2011JD017161.

Shukla, S.P., Sharma, M., 2010. Neutralization of rainwater acidity at Kanpur, India. Tellus 62B, 172-180.

U.S. Environmental Protection Agency, 2012. Cloud Deposition Monitoring. Great Smoky Mountains National Park, Clingmans Dome, TN. Summary Report, October 2012.

Wang, Y., Guo, J., Wang, T., Ding, A., Gao, J., Zhou, Y., Collett Jr., J., Wang, W., 2011. Influence of regional pollution and sandstorms on the chemical composition of cloud/fog at the summit of Mt. Taishan in northern China. Atmos. Res. 99, 434442.

Weatherburn, M.W., 1967. Phenol-hypochlorite reaction for determination of ammonia. Anal. Chem. 39, 971-974. 